\title{
PEMIKIRAN TEOLOGIS KAUM SALAFÎ: Studi atas Pemikiran Kalam Ibn Taymiyah
}

\author{
Izzuddin Washil* dan Ahmad Khoirul Fata * * \\ * IAIN Syekh Nurjati Cirebon \\ ** IAIN Sultan Amai Gorontalo \\ E-mail: izzuddinwashil@gmail.com
}

\begin{abstract}
In the field of kalam (Islamic theology), some major themes, like attributes of Allah, will of Allah and human freedom, or Quran as words of Allah, have become debate topics between thought schools of kalam in Islam. Because of the complexity of those topics, the debate becomes eternal, without an agreed end. Among those thought schools of kalam in Islam involved in the debate is salaf school, held by Ibn Taymiyah. In his opinion, the school is the right one because it quite conforms to Quran and sunna. By way of thought (manhaj) of salaf school, Ibn Taymiyah also takes part in explaining those major themes in his works. In the case of the will of Allah and human freedom, for example, he doesn't agree with the Qadarite school's thought and the Jabarite school's thought although in this he hasn't yet stretched out a convincing explanation. This essay will analyze the way of thought (manhaj) of salaf school and Ibn Taymiyah's opinion about those major themes, especially in his book Majmîn' al-Fatâwâ.
\end{abstract}

Dalam bidang kalam (teologi Islam), beberapa tema utama, seperti sifatsifat Allah, kehendak Allah dan kebebasan manusia, atau Alquran sebagai perkataan Allah, telah menjadi topik perdebatan di antara mazhab pemikiran kalam dalam Islam. Karena peliknya, perdebatan itu seolah menjadi perdebatan abadi tanpa ujung yang disepakati. Di antara mazhab pemikiran kalam yang terlibat dalam perdebatan itu adalah mazhab salaf, 
yakni mazhab yang diikuti oleh Ibn Taymiyah, yang menurutnya adalah mazhab yang paling benar karena paling sesuai dengan Alquran dan sunah Nabi. Melalui manhaj mazhab salaf, Ibn Taymiyah juga ambil bagian dalam menjelaskan tema-tema utama di atas dalam berbagai kitabnya. Dalam hal kehendak Allah dan kebebasan manusia, misalnya, ia tidak sependapat dengan pendapat mazhab Qadariyyah dan Jabariyyah walaupun ia sendiri belum memberikan penjelasan yang meyakinkan. Tulisan ini akan menguraikan manhaj mazhab salaf dan pandangan Ibn Taymiyyah mengenai tema-tema utama tersebut sebagaimana yang termuat dalam karya-karyanya, khususnya dalam kitab Majmî'al-Fatâwâ.

Keywords: Ibn Taymiyah's kalam; thought of kalam schools; thought of salaf school

Received: September 4, 2018; Accepted: November 21, 2018

\section{Pendahuluan}

Ibn Taymiyah dikenal sebagai pembaharu yang memberikan warna dalam peradaban Islam hingga kini. Gagasan-gagasannya yang tegas merujuk ke Alquran dan hadis serta salaf șâlih telah mengilhami gerakan pembaharuan dan pemurnian Islam di kemudian hari. Ia dianggap sebagai seorang mujtahid (Sucipto 2011) dan tokoh gerakan Salafî, bahkan sebagai pendirinya. Tokoh lain yang menjadi rujukan kaum Salafî adalah Aḥmad ibn Hanbal pendiri mazhab fikih Hanâbilah (Ardiansyah 2013). Selain mengajak kembali Alquran dan hadis, Ibn Taymiyah juga secara tegas menolak pemikiran dan tradisi lain yang dinilai bukan bersumber dari ajaran Islam yang otentik. Islam otentik menurut kaum Salafî adalah Islam yang terwujud pada zaman Nabi Muhammad dan para salaf alsâalih (Washil dan Fata 2017).

Meski demikian, Nurcholish Madjid melihat Ibn Taymiyah secara berbeda. Menurutnya, Ibn Taymiyah merupakan tokoh yang memiliki corak pemikiran yang inklusif. Kesimpulan Madjid ini bersumber dari pemaknaan Ibn Taymiyah tentang "Islâm" sebagai al-istislâm (sikap berserah diri), alinqiyâd (tunduk patuh), dan alikhlâs (sikap tulus). Sikap seperti ini diajarkan oleh semua nabi-nabi dan ditegaskan dalam kitab suci para rasul. Dengan mengutip pendapat Ibn Taymiyah, Madjid pun menyimpulkan bahwa pangkal semua agama itu sama, hanya saja syariatnya yang berbeda-beda 
(Nurcholish Madjid 1992). Namun hal ini dibantah oleh Noorhayati dan Fata yang melihat bahwa Madjid kurang tepat dalam mengambil kesimpulan. Menurut keduanya, pemikiran Ibn Taymiyah lebih tepat dikategorikan sebagai eksklusif ketimbang inklusif (Noorhayati dan Fata 2017).

Sikap tegas kelompok-kelompok Salafî sering diidentikkan dengan kekerasan dan fundamentalisme. Kesan ini begitu terasa, khususnya pasca kampanye Amerika untuk melawan terorisme dan radikalisme. Akibatnya, banyak komunitas Salafî yang dilihat masyarakat dengan negatif dan penuh kecurigaan. Meskipun hal itu belum tentu benar. Penelitian yang dilakukan oleh Damayanti dan Pierewan tentang komunitas Salafî di Yogyakarta membuktikan hal tersebut tidak lebih hanya sekedar prasangka sosial yang segera memudar seiring dengan intensitas interaksi sosial yang terjadi di antara mereka (Damayanti dan Pierewan 2016). Kesimpulan serupa juga dinyatakan oleh Rohmaniyah dan Woordward sebelumnya. Dalam penelitian keduanya terhadap beberapa sekolah-sekolah yang dianggap Wahhâbî, keduanya menemukan fakta bahwa toleransi antar-agama dan sikap anti kekerasan justru menjadi identitas mereka. Kesimpulan ini membantah apa yang berkembang di masyarakat tentang kelompok SalafîWahhâbî (Rohmaniyah dan Woodward 2012). Begitu pula penelitian Afwadzi dan Alifah yang membuktikan adanya pemikiran non-eksklusif dan fleksibel dengan mengakomodir lokalitas sebuah wilayah dan keilmuan astronomi Islam dalam fatwa salah satu ulama Salafî, al-'Uthaymîn terkait dengan waktu puasa Arafah (Afwadzi dan Alifah 2017).

Kelompok salaf sendiri, menurut Ibn Taymiyah, memiliki kekhasan yang membedakannya dari kelompok-kelompok Islam lainnya. Dalam hal ini, Ibn Taymiyah membagi ulama dalam memahami akidah Islam ke dalam empat kategori. Pertama, para filsuf. Mereka mengatakan bahwa Alquran datang dengan metode instruksional dan premis-premis yang dapat diterima masyarakat. Mereka menegaskan bahwa diri mereka adalah kelompok pakar di bidang argumentasi dan keyakinan, sedang metode akidah adalah argumentasi dan keyakinan. Kedua, para pakar ilmu kalam, yaitu Mu'tazilah. Mereka mengemukakan berbagai kesimpulan yang rasional sebelum mengadakan penalaran terhadap ayat-ayat Alquran. Mereka berpegang pada dua bentuk argumentasi (naqlî dan 'aqlî), tetapi mereka mendahulukan penalaran rasional daripada dalil Alquran. Mereka menakwilkannya sesuai dengan tuntutan akal, sekalipun mereka tidak keluar dari akidah Alquran. 
Ketiga, kelompok ulama yang mengadakan penalaran terhadap akidah yang terdapat di dalam Alquran untuk diimani, dan dalil-dalil yang terkandung di dalamnya untuk digunakan. Dalil-dalil itu digunakan bukan karena merupakan dalil yang memberikan petunjuk dan bimbingan yang mengarahkan akal untuk mencari berbagai premis di sekitarnya, melainkan karena merupakan sejumlah ayat informatif yang isinya wajib diimani, tanpa menjadikannya sebagai premis bagi istinbât al'aqlî. Keempat, kelompok orang yang beriman kepada Alquran, baik akidah maupun dalilnya, tetapi mempergunakan dalil rasional di samping dalil Alquran itu (Abû Zahrah 1996).

Dari pembagian ini, Ibn Taymiyah pun menegaskan bahwa kelompok salaf tidaklah termasuk salah satu di antara empat kategori di atas (Abû Zahrah 1996), karena mereka mempunyai metode (manhaj) tersendiri dalam rumusan-rumusan kalam-nya. Artikel ini ingin membahas manhaj Salafî tersebut melalui pemikiran tokoh utamanya, Ibn Taymiyah. Kajian atas pemikiran kalam tokoh utama Salafî itu diharapkan dapat memberikan gambaran akar basic structure paradigma teologis Salafî. Untuk itu penulis akan merujuk langsung kepada sumber primer karya Ibn Taymiyah, yaitu Majmî al-Fatâwâa agar dapat mengungkapkan pemikirannya secara lebih otentik. Dengan demikian, kajian ini bisa melengkapi kajian-kajian tentang salafisme yang selama ini, kebanyakan, masih di ranah empirik; Salafî sebagai fenomena sosial dan politik. Kajian ini juga akan melengkapi beberapa kajian tentang pemikiran Ibn Taymiyah dengan penegasan bahwa sang pembaharu itu merupakan peletak dasar-dasar mazhab Salafî.

\section{Sketsa Biografis Ibn Taymiyah}

Nama lengkapnya adalah Ahmad Taqiyy al-Dîn Abû al-Abbâs ibn al-Shaykh Shihâb al-Dîn Abî al-Mahâasin 'Abd al-Hâlim ibn al-Shaykh Majd al-Dîn Abî al-Barakat 'Abd al-Salâm ibn Abî Muhammad 'Abd Allâh ibn Abî al-Qâsim al-Khudrî ibn Muhammad ibn 'Alî ibn 'Abd Allâh. Ia populer disebut dengan nama Shaykh al-Islâm Ibn Taymiyyah. Pembaharu yang biasa dipanggil dengan Ibn Taymiyah atau Shaykh al-Islâm itu dilahirkan pada tanggal 10 Rabi' al-Awwal $661 \mathrm{H} / 22$ Januari 1263 M di kota Harran dekat Damaskus.

Ayahnya, Shaykh Shihâb al-Dîn, merupakan orang alim di negerinya. Ia mengajar dan memberikan petunjuk dan fatwa di masjid Jami‘ Damaskus. Kakeknya, Majd al-Dîn, adalah seorang alim ahli fikih mazhab 
Hanbalî pada masanya. Dalam lingkungan keluarga yang demikian itu, memungkinkan Ibn Taymiyah untuk menuntut ilmu sejak kecil. Pada usianya yang relatif muda ia telah hafal Alquran. Setelah itu, ia mulai mempelajari hadis, fikih, bahasa, dan ilmu pasti. Ia dengan tekun mempelajari fikih Hanbalî, karena ayahnya termasuk pemuka mazhab itu. Pada kesempatan lain, ia mendalami ilmu tafsir dan akidah (Abû Zahrah n.d.).

Ibn Taymiyah harus meninggalkan kampung halamannya dan pindah ke Damaskus bersama ayahnya, 'Abd al-Hâlim, dan tiga saudaranya karena serbuan tentara Mongol. Di sana, ayahnya menjadi direktur Madrasah Sukkariyya. Di madrasah ini pula Ibn Taymiyah belajar. Beberapa guru Ibn Taymiyah di sekolah tersebut adalah Shams al-Dîn 'Abd alRaḥmân al-Makdisî, yang merupakan seorang qậ̂̉ Hanbalî pertama di Syria setelah reformasi kehakiman oleh Baybars. Ibn Taymiyah kemudian menggantikan ayahnya di kantor Sukkariyya, dan pada 2 Muharram 683/21 Maret 1284 dia diperbolehkan mengajar untuk pertama kalinya. Pada 10 Safar 684/17 April 1285 ia mulai mengajar tafsir Alquran di Masjid Umayyah (Madjid 1992).

Ibn Taymiyah melakukan perjalanan haji pertama kali pada tahun 691 H/1292 M dan kembali ke Damaskus sekitar empat bulan kemudian. Dari perjalanan spiritual ini ia menghasilkan karya Manâsik al-Ḥajj yang berisi kritiknya terhadap praktek-praktek bid'ah yang terjadi dalam ritual haji di Tanah Suci. Selain aktif di bidang sosial keagamaan, Ibn Taymiyah juga terlibat aktif dalam pergumulan politik di negaranya. Ia pertama kali tercatat berurusan dengan politik saat kasus pelecehan terhadap Nabi Muhammad oleh 'Assaf al-Nașrânî, seorang Kristen dari Suwayda. Ketegasan sikapnya membuat ia dipenjara untuk pertama kalinya. Dalam kondisi seperti ini, ia menghasilkan satu karya besar berjudul "al-Sarîm alMaslûl 'alâ Shâtim al-Rasûl." Pada 20 Juni 1296 ia mengajar di madrasah tertua di Damaskus, Hanbaliyyah, menggantikan salah satu guru di situ yang meninggal dunia.

Dalam rentang hidupnya, Ibn Taymiyah menghadapi situasi politik yang tidak stabil. Perpecahan yang terjadi di antara pemimpin negara-negara Islam serta serangan dari negara luar, khususnya dari Mongol selalu menghantui masyarakat Muslim. Tercatat pada tahun 1297-1299 M di era kekuasaan al-Mâlik al-Manșûr, Ibn Taymiyah diminta Sultan untuk menyerukan jihad melawan kerajaan Armenia Kecil (little Armenia). Tahun 
1300 M dia diminta untuk menyerukan jihad melawan Mongol, dan pada tahun 1301 ia pergi ke Kairo untuk meminta penguasa Mamluk Sultan Muhạmmad ibn Qalâwûn untuk mengintervensi Syria. Pada saat yang sama muncul serangan baru dari Mongol (Abû Zahrah n.d.).

Ibn Taymiyah juga aktif terlibat dalam pergolakan pemikiran di dunia Islam saat itu. Ia "menyerang" Shaykh Ibrâhîm al-Khabbâz yang dinilainya anti-nomianisme. Di saat yang hampir bersamaan dia pergi bersama tukang batu untuk menghancurkan batu suci (sacred rock) di masjid al-Narandi. Ibn Taymiyah juga "menyerang" kelompok Ittihâdiyyah pendukung Ibn 'Arabî. Aksi kritisnya juga mendorongnya untuk mengirim surat ke penasehat Baybars yang berisi kutukan terhadap monisme Ibn "Arabî. Ibn Taymiyah terlibat dalam ekspedisi melawan Rawâfị̣ dari Kasrawân, dan di Damaskus ia "menyerang" Aḥmadiyyah Rifâ'iyyah, seorang shaykh yang dituduh menjadi simpatisan Mongol (Abû Zahrah n.d.).

Di bawah kekuasaan Gubernur Damaskus, Tankîz (w. 740 H/1340 M), Ibn Taymiyah dipromosikan sebagai Guru Besar dan para pengikutnya mengangkatnya sebagai seorang mujtahid. Ibn Taymiyah termasuk ulama yang produktif. Ia memiliki banyak karya di berbagai bidang, seperti al-Radd 'alâ al-Manțiqiyyîn, al-Siyâsat al-Shar'iyyah, Fatâwâ Mișriyyah, Minhâj al-Sunnah al-Nabawiyyah, Ziyârat al-Qubûr, Kitâb Ma'rifat al-Wuṣûl, dan Kitâb al-Radd 'alâ al'ikhna'. Hasil karya yang tidak boleh dilupakan adalah beberapa karyanya yang lain, yaitu Majmû́at al-Rasấil (2 vol), Majmû'at al-Rasâ'il alKubrâ, Kitâb Majmû'at al-Fatâwâ, Majmû'at al-Rasâ’il wa al-Masâ'il (5 vol), dan yang terbesar adalah Kitâb Majm û' al-Fatâwâ Shaykh al-Islâm Ahmad ibn Taymiyyah (30 vol). Selain itu juga terdapat beberapa karyanya yang dikumpulkan oleh murid-muridnya, seperti Ibn al-Qayyim al-Jawzî yang mengumpulkan karya-karyanya dalam buku berjudul Asmâ' Mu'allafât Ibn Taymiyyah (Abû Zahrah n.d.).

Keberanian Ibn Taymiyah dalam menulis sama besarnya dengan keberaniannya dalam berpidato. Ia tidak pernah ragu-ragu dalam mengemukakan sesuatu yang diyakininya sebagai kebenaran, walaupun di depan para ulama, pejabat, dan penguasa yang menentangnya. Akibatnya, ia berulangkali masuk keluar penjara. Pada bulan Rajab 720 H/Agustus 1320 $\mathrm{M}$ ia ditangkap dan dipenjara di Damaskus selama lima bulan karena fatwanya yang bertentangan dengan pendapat ulama ketiga mazhab non- 
Hanbalî, yakni Hanafî, Mâlikî, dan Shâfi'î. Kemudian, ia ditangkap dan dipenjara lagi pada tanggal 16 Sya'ban $726 \mathrm{H} / 18$ Juli $1326 \mathrm{M}$.

Meskipun berkali-kali masuk-keluar penjara, namun itu tidak menjadikannya jera. Penjara tidak menyakitkan baginya. Justru pengalaman yang paling menyakitkannya adalah ketika Mâlik ibn Nașr, atas perintah penguasa, pada tanggal 9 Jumadil Akhir menyita semua barang berharga miliknya berupa kertas, tinta, dan pena serta kitab-kitab yang ditulisnya dalam jumlah kurang lebih 60 jilid dan 14 bundel catatan-catatannya yang ada di kamar penjaranya. Lima bulan kemudian setelah menderita sakit selama dua puluh hari, ia meninggal dunia di dalam penjara pada tanggal 20 Dzul Qa'dah 728 H/26 September 1328 M. Jenazahnya diantarkan oleh sejumlah besar penduduk Damaskus menuju makam, tidak kurang dari dua ratus ribu laki-laki dan lima belas ribu perempuan (Chirzin 1999).

\section{Mazhab Kalam Ibn Taymiyah: Mazhab Salaf}

Secara umum pemikiran Ibn Taymiyah terinspirasi oleh mazhab Hanbalî. Ini normal belaka mengingat ia menghabiskan sebagian besar pendidikannya dalam lingkungan mazhab ini. Ia berupaya untuk menyintesiskan pengetahuan yang bersumber dari akal (reason), tradisi yang bersumber dari naql, dan doktrin irâdah atau free-will dalam sufi. Ketiganya merupakan tiga elemen penting yang dicoba untuk diintegrasikan dan diharmoniskan dalam sebuah konstruk doktrin yang kokoh yang biasa disebut "reformisme konservatif." Dalam wilayah dogma, Ibn Taymiyah memfokuskan untuk mengikuti Alquran dan sunah karena dengan keduanya manusia bisa mengenal Tuhan sebagaimana Tuhan mendeskripsikan Dirinya sendiri dalam kitab-Nya, dan sebagaimana Nabi Muhammad mendeskripsikan Tuhan dalam sunahnya (Chirzin 1999).

Di kemudian hari, Ibn Taymiyah memberikan pengaruh besar dalam dunia Islam, terutama di lingkungan Sunnî. Ia dianggap setara dengan dua tokoh besar lainnya, yaitu Imâm al-Ghazâlî dan Ibn 'Arabî. Salah satu tokoh yang terinspirasi oleh Ibn Taymiyah adalah Muhammad ibn 'Abd al-Wahhâb yang mempelopori gerakan purifikasi ketat terhadap praktik beragama di tanah Arab dan tokoh ideolog negara Arab Saudi di bawah dinasti Saud. Purifikasi 'Abd al-Wahhâb ini kemudian dikenal sebagai gerakan Wahhâbî atau Wahhabisme (Chirzin 1999).

Dalam kajian ilmu kalam, mazhab salaf termasuk salah satu di antara mazhab-mazhab teologis Islam yang lain. Mazhab ini muncul pada abad ke-4 Hijriyah. Mereka terdiri dari ulama pengikut mazhab Hanbalî 
yang berpendapat bahwa garis besar pemikiran mereka bermuara pada pemikiran Ahmad ibn Hanbal yang menghidupkan akidah ulama salaf dan berusaha memerangi paham lainnya (Ardiansyah 2013; Abû Zahrah 1996). Ciri khas mereka adalah kembali kepada penafsiran harfiyah atas nas-nas agama. Mereka juga memunculkan tradisi teologis (kalam) dan hukum (fikih) sebagaimana ketika perkembangan pertama dalam Islam serta menolak dominasi akal dalam memecahkan berbagai masalah keagamaan.

Merujuk kepada Alquran, hadis, dan ajaran salaf alsâalih diterapkan kelompok Salafî dalam pemahaman dan praktik keagamaan secara tegas. Dalam penafsiran Alquran misalnya, Ibn Taymiyah menilai bahwa metode tafsir terbaik adalah tafsî bi al-ma'th $\hat{u}$, karena sesungguhnya ayat Alquran saling menjelaskan satu sama lain (yufassiru ba'duhum ba'dan). Begitu juga dengan hadis yang berfungsi sebagai penjelas Alquran. Menurutnya, tidak ada seorang pun yang lebih mengetahui Allah dan ajaran-ajaran-Nya kecuali Nabi Muhammad karena dia telah diutus oleh Allah untuk menyampaikan ajaran-ajaran itu. Dengan demikian, Ibn Taymiyah menolak penggunaan ta'wîl, ia menolak adanya ta'wîl dan majaz dalam penafsiran. Menurutnya, para pelaku bid'ah seringkali menggunakan Alquran dan hadis jika sesuai dengan keinginan mereka. Namun apabila tidak, mereka mengubah makna lahir teks ke makna yang sesuai dengan apa yang mereka maksud (Hudaya 2008).

Sementara sikap tegas Ibn Taymiyah terhadap hal-hal yang dianggapnya tidak sesuai dengan Islam ditunjukkan pada kritiknya terhadap ajaran tasawuf. Menurutnya, beberapa ajaran tasawuf yang berkembang saat itu sudah menyimpang jauh dari Islam, karena itu harus ditolak. Dalam hal ini, Ibn Taymiyah secara tegas menolak dua hal dalam tasawuf, yaitu: doktrin tentang kesatuan hamba dengan Tuhan (wahdat al-wujûd) dan fana' yang banyak dianut kalangan sufi aliran falsafi. Menurutnya, tasawuf yang benar adalah yang bersumber dari syariat dan berujung kepada syariat. Karena itulah, tasawuf yang dikembangkan Ibn Taymiyah lebih bercorak tasawuf akhlâqî (Washil dan Fata 2017).

Secara lebih terinci, Hudaya melihat corak pemikiran tasawuf Ibn Taymiyah sebagai tasawuf Salafî, bukan tasawuf Sunnî. Menurutnya, tasawuf Salafî merupakan aliran tasawuf yang ajaran-ajaran dan metodemetodenya dipandu secara ketat oleh Alquran dan sunah Nabi Muhammad sebagaimana yang dipraktikkan oleh $\mathrm{Nabi}$ dan para generasi salaf. Sementara tasawuf Sunnî tetap berpedoman dengan Alquran dan hadis, 
namun ada upaya untuk mengombinasikannya dengan realitas yang ada. Metode yang digunakannya terkadang berbeda dengan yang dilakukan para salaf al-sâlih. Meski demikian, kedua corak sufisme ini secara diametral bertentangan dengan tasawuf falsafi yang mengajarkan pengikutnya ajaran tentang kesatuan Tuhan dengan manusia dalam bentuk ittihâd, hulûl, atau wahdat al-wujûd (Hudaya 2008).

Di bidang pemikiran kalam, Ibn Taymiyah juga banyak mengritik kalangan Ash'ariyah yang dianggapnya saling bertentangan satu sama lain. Kritiknya pada kalangan Ash'ariyah ini membuatnya berkesimpulan bahwa ilmu yang tersusun di atas dasar-dasar ilmu yang asing dari manhâj al-fikr pada zaman Rasulullah dan para sahabatnya, yang dalam hal ini ia mencontohkan ilmu kalam, termasuk ilmu yang tercela (Abû Zahrah 1996).

Mazhab salaf terilustrasikan dengan jelas pada peristiwa mihnah yang dilakukan oleh Gubernur Baghdâd Ishâa ibn Ibrâhîm terhadap Aḥmad ibn Hanbal sebagaimana berikut:

Ishạâ ibn Ibrâhîm : Apakah Alquran itu makhluk?

Ahmad ibn Hanbal : Alquran itu kalam Allah.

Ishậq ibn Ibrâhîm : Apakah ia makhluk?

Ahmad ibn Hanbal : Kalam Allah, dan saya tidak akan menambah lebih daripada itu.

Ishâq ibn Ibrâhîm : Apakah pengertian Allah itu Maha Mendengar dan Maha Melihat?

Aḥmad ibn Hanbal : Seperti yang dimaksud Allah dengan sifat diri-Nya.

Ishâq ibn Ibrâhîm : : Apa pengertiannya?

Ahmad ibn Hanbal : Saya tidak tahu. Allah lebih tahu akan sifat diri-Nya (Mansur 1994).

Di antara tokoh terkenal yang melanjutkan mazhab ini adalah Ibn Taymiyah. Menurutnya, mazhab salaf adalah mazhab yang benar, karena sesuai dengan Kitab (Alquran) dan sunah Nabi. Bagi Ibn Taymiyah, salaf merupakan mazhab yang paling mengerti dan paling bagus pemahamannya terhadap nas. Setiap mazhab yang bertentangan dengan akidah mereka, maka mazhab tersebut adalah batil dan wajib ditolak (al-Mahmûd 1995).

Secara garis besar, manhaj mazhab salaf adalah sebagai berikut (alMahmûd 1995; Abû Zahrah 1996):

1. Mencukupkan diri pada Alquran dan sunah. 
Kaidah ini mengandung beberapa kesimpulan:

a. Keselamatan hidup dan rida Allah hanya bisa dicapai dengan jalan iman kepada keduanya dan beramal sesuai dengan apa yang datang dari keduanya.

b. Agama (Islam) ini sempurna. Hal ini berdasarkan beberapa ayat dalam Alquran, misalnya Q.S. al-Mâ'idah [5]: 15-16.

"Hai Ahli Kitab, sesungguhnya telah datang kepadamu Rasul kami, menjelaskan kepadamu banyak dari isi al-Kitab yang kamu sembunyikan, dan banyak (pula yang) dibiarkannya. Sesungguhnya telah datang kepadamu cahaya dari Allah, dan kitab yang menerangkan."

"Dengan kitab Itulah Allah menunjuki orang-orang yang mengikuti keridhaan-Nya ke jalan keselamatan, dan (dengan kitab itu pula) Allah mengeluarkan orangorang itu dari gelap gulita kepada cahaya yang terang benderang dengan seizinNya, dan menunjuki mereka ke jalan yang lurus."

c. Wajib mendahulukan syara di atas akal jika keduanya bertentangan, walaupun dalam kenyataannya keduanya tidak mungkin bertentangan.

2. Tidak memasuki dunia kalam dan falsafah dan hanya berpegang pada Kitab (Alquran) dan sunah Nabi dalam menjelaskan dan memahami persoalan-persoalan akidah.

Hal ini mengandung beberapa pengertian:

a. Memelihara ilmu yang bermanfaat disertai dengan amal perbuatan. Ada dua macam ilmu, yakni ilmu yang bermanfaat yang melahirkan amal dan bermanfaat bagi pemiliknya di dunia dan akhirat dan ilmu yang tidak bermanfaat bagi pemiliknya di dunia dan akhirat.

b. Menolak adanya bid'ah. Di antaranya adalah ilmu kalam. Penolakan ini bukan karena kelemahan atau kebodohan mereka, tetapi karena ilmu kalam dipandang sebagai ilmu yang berdiri di atas dasar-dasar ilmu yang asing (asas gharabiyah) dari manhaj pada zaman Rasul dan Sahabatnya.

3. Kehujjahan hadis-hadis sahih dalam masalah akidah, termasuk hadis (khabar) ahâd.

4. Sahabat adalah generasi setelah Rasul yang paling mengetahui masalahmasalah akidah. Perkataan-perkataan dan penafsiran-penafsirannya pada nas menjadi hujjah bagi kaum muslimin.

5. Menerima setiap yang datang dari wahyu disertai pemahaman akal yang benar dan tidak memasuki masalah-masalah gaib yang akal tidak 
mempunyai tempat baginya. Kaum salaf bukanlah menafikan akal sebagaimana yang dituduhkan oleh ahli kalam. Bagi mereka, wahyu datangnya dari Allah, sementara akal adalah salah satu di antara makhluk-Nya, keduanya tidak mungkin bertentangan.

\section{Poin-poin Penting Pemikiran Kalam Ibn Taymiyah}

Manhaj salaf yang diyakini sebagai manhaj yang benar oleh Ibn Taymiyah telah membawanya pada suatu pendirian kalam yang mempunyai ciri khas tersendiri di tengah-tengah mazhab kalam yang lain. Sesekali terdapat kesamaan pendirian di antara mereka dan sesekali terdapat juga perbedaan yang jauh. Untuk mendapatkan gambaran yang lebih jelas mengenai pemikiran kalam Ibn Taymiyah agar bisa ditentukan posisi pemikiran kalamnya di antara berbagai mazhab kalam lainnya, berikut ini dipaparkan beberapa contoh pemikirannya mengenai persoalan-persoalan kalam:

\section{Sifat-sifat Allah}

Menurut Ibn Taymiyah, termasuk iman kepada Allah adalah iman kepada sifat-sifat-Nya sebagaimana yang terdapat dalam Kitab-Nya dan melalui lisan Rasul-Nya, Muhammad Saw., tanpa tahrîf (mengubah lafal atau makna nama dan sifat), ta'tîl (menghilangkan atau meniadakan sifatsifat Allah), takyîf (menerangkan bentuk atau keadaan sifat itu) dan tamthîl (penyerupaan dengan makhluk) (al-Ḥanbalî 1425 H; al-Sa'dî 2001), dan pengetahuan yang benar mengenai makna dan hakikatnya diserahkan kepada Allah semata, karena Allahlah yang menyifati dan menamai diri-Nya sendiri dalam Kitab atau melalui lisan Rasul-Nya (al-Hanbalî $1425 \mathrm{H}$ ).

Ibn Taymiyah tidak mempersoalkan masalah sifat Allah ini dalam persinggungannya dengan masalah Zat Allah sebagaimana yang dilakukan oleh kalangan Ash'ariyah dan Mu'tazilah. Baginya, Zat Allah itu lebih besar daripada apa yang terjangkau oleh pikiran manusia. Akal dan pikiran tidak akan mampu menemukan hakikat Zat Allah, karena itu kita dilarang memikirkan Zat Allah untuk menjauhkan kita dari hal yang akal tidak mungkin melakukannya (Chirzin 1999).

Ash'ariyah berpendapat bahwa Allah mempunyai beberapa sifat seperti mengetahui (Âlim bi 'ilm), berkuasa (Qâdir bi qudrat), berkehendak (Mûrid bi alirâdat) dan sebagainya, tetapi sifat-sifat ini ada bersamaan dengan Zat-Nya (azaliyat qầ'imat bi dhâtihi). Untuk menghindari banyaknya 
Zat yang qadìm (ta'addud al-qudamâ'), mereka memunculkan konsep Lâ Hiya Huwa wa Lâ Hiya Ghayruhu (bahwa sifat-sifat itu bukanlah Allah itu sendiri tetapi bukan pula selain Allah) (al-Shahrastânî n.d.). Sementara bagi Mu'tazilah, Allah itu tidak mempunyai sifat. Sifat dalam pengertian Ash'ariyah adalah Zat itu sendiri menurut $\mathrm{Mu}$ 'tazilah. Allah itu mengetahui dengan-Nya, atau berkuasa, hidup dan sebagainya adalah dengan Zat-Nya bukan dengan sifat-Nya (Âlimun li dhâtihi, Qâdirun Hayyun li dhâtihi) (Nasution 1972).

Karena Ibn Taymiyah tidak mempersoalkan hubungan antara sifat Allah dan Zat Allah sebagaimana perdebatan yang terjadi antara kaum Ash'ariyah dan $\mathrm{Mu}$ 'tazilah di atas, maka dalam masalah ayat-ayat anthropomorphisme (keserupaan sifat-sifat ketuhanan dengan sifat-sifat kemanusiaan), Ibn Taymiyah lebih dekat dengan kalangan Ash'ariyah. Mereka (kaum Ash'ariyah) berpendapat bahwa Allah mempunyai sifat-sifat anthropomorphistik, tetapi sifat-sifat Allah itu tidak sama dengan yang dipunyai oleh manusia dan tidak boleh ditafsirkan (bilâ kayfa) (Nasution 1972). Pendapat ini berbeda dengan kalangan Mu'tazilah. Menurut $\mathrm{Mu}$ 'tazilah, ayat-ayat ini harus diberi interpretasi lain. Kata al-Arsh misalnya diberi interpretasi kekuasaan, al'Ayn diartikan pengetahuan, al-Wajh ialah esensi, dan al-Yad adalah kekuasaan (Nasution 1972).

\section{Kehendak Allah dan Kebebasan Manusia}

Dalam hal ini, Ibn Taymiyah mempunyai pendapat yang tampak bertentangan (ambivalen). Di satu sisi, Ibn Taymiyah mengakui bahwa Allah adalah pencipta segala sesuatu, termasuk perbuatan hamba (manusia), dan jika Allah menghendaki sesuatu, maka jadilah sesuatu itu, dan apa yang tidak dikehendakinya, maka tidak akan terjadi:

$$
\text { ... بأن الله خالق كل شئ من أفعال العباد وغيرها، وأنه ماشاءالله كان ومالم يشأ لم يكن }
$$

“... Karena sesungguhnya Allah merupakan pencipta setiap sesuatu, dari perbuatan-perbuatan hamba dan selainnya. Dan sesungguhnya apa yang Dia kehendaki akan terjadi, dan apa-apa yang tidak Dia kehendaki tidak akan terjadi” (al-Hanbalî $1425 \mathrm{H}$ ).

Namun di sisi lain, ia juga berpendapat bahwa hamba ('abd) adalah pelaku (fấil) yang sebenarnya: 
"Dan hamba adalah pelaku yang sejati" (al-Hanbalî 1425 H)

Pada bagian lain, ia mempertegas ambivalensinya tersebut. Ia menyatakan:

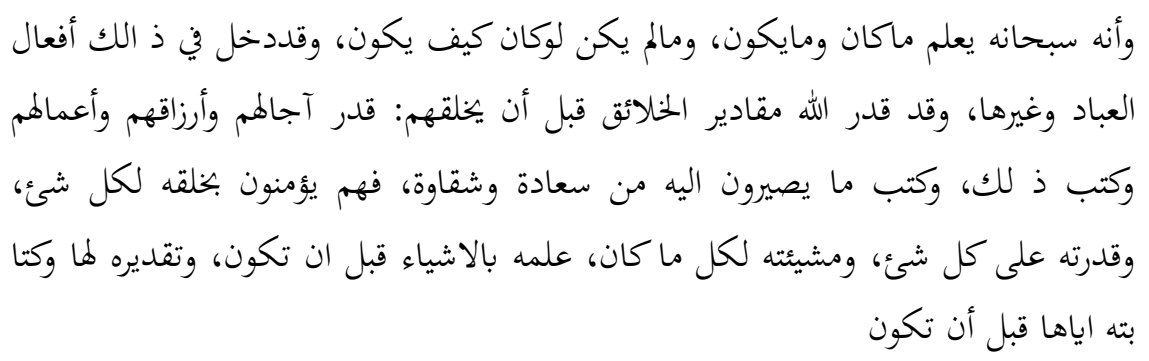

"Dan sesungguhnya Allah Swt. mengetahui sesuatu yang telah terjadi dan sesuatu yang sedang terjadi, dan (mengetahui) sesuatu yang belum terjadi, jika itu terjadi (maka) Allah mengetahui bagaimana kejadiannya. Termasuk dalam pengertian apa yang terjadi ini adalah perbuatan hamba dan selainnya. Allah telah menentukan ukuran-ukuran (ketentuan-ketentuan) para mekhluk sebelum Ia menciptakan mereka, Allah menentukan ajal mereka, dan Allah menetapkan semuanya itu. Allah menetapkan kebahagiaan dan kesengsaraan mereka ketika mereka kembali (kepada Allah). Mereka mengimani ciptaan Allah pada segala sesuatu, ketentuan-Nya atas segala sesuatu, dan kehendak-Nya atas segala yang sudah terjadi. Ketentuan-Nya pada segala sesuatu dan ketetapan-Nya pada mereka ada sebelum terjadi” (al-Hanbalî 1425 H).

Tetapi pada saat yang sama, ia juga menulis:

$$
\text { ... أن العباد لهم مشيئة وقدرة يفعلون بمشيئتهم وقدرةم ما اقدهم الله عليه. }
$$

“... Sesungguhnya hamba, bagi mereka kehendak dan kemampuan. (Hamba) berbuat dengan kehendak dan kemampuan mereka, sesuatu yang telah Allah tetapkan bagi mereka" (al-Hanbalî $1425 \mathrm{H}$ ).

Sampai di sini, apa yang menjadi pendiriannya mengenai kehendak Allah sangat mirip dengan pendirian kalangan Jabariyah yang berpendapat 
bahwa manusia itu terpaksa (majbûr) dalam segala tindakannya dan tidak mempunyai pilihan dan kekuasaan dalam bertindak. Sementara itu, pendapatnya mengenai kebebasan manusia menyerupai kalangan Qadariyah yang berpendapat bahwa manusia itu tidaklah terpaksa, tetapi ia bebas untuk memilih (mukhtar harr) perbuatan-perbuatannya. Manusia berkuasa untuk mengerjakan atau meninggalkan sesuatu. Tidak ada penguasa bagi kehendaknya (al-Gharabî 1958).

Walaupun demikian, ia menolak disamakan dengan kelompok Jabariyah, karena menurutnya Jabariyah sama sekali menafikan peran perbuatan manusia sebagai konsekuensi dari keyakinannya bahwa manusia itu majbûr (terpaksa). Ibn Taymiyah menolak keyakinan ini dengan perkataannya:

$$
\begin{aligned}
& \text {....فلم يكن من السلف والأئمة من يقول: ان العبد ليس بفاعل ولامختار، ولامريد ولاقاد ر. }
\end{aligned}
$$

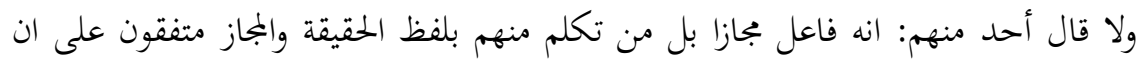

$$
\begin{aligned}
& \text { العبد فاعل حقيقة والله تعالى خالق ذاته وصفاقوافعاله. }
\end{aligned}
$$

“... Kaum salaf dan para imam tidak ada yang berkata: '(seorang) hamba bukan pelaku sebenarnya (dari perbuatan-perbuatannya). Ia juga tidak merdeka, tidak punya kehendak, dan tidak punya kekuasaan.' Tidak juga di antara mereka berkata: ' (seorang) hamba adalah pelaku majaz belaka.' Dalam hal ini mereka berkata dengan lafal hakikat dan majaz. Mereka sepakat bahwa (seorang) hamba adalah pelaku sebenarnya (hakikat) dari perbuatan-perbuatannya, sementara Allah adalah pencipta zat-Nya, sifat-sifat-Nya, dan perbuatan-perbuatan-Nya" (alHanbalî 1425 H).

Dengan demikian, sebagaimana pendapatnya di atas, Ibn Taymiyah mengakui bahwa hamba ('abd) adalah pelaku sebenarnya dari perbuatanperbuatan yang dilakukannya. Tetapi pengakuan ini bukan berarti ia sependapat dengan paham Qadariyah. Sebagaimana ia menolak paham Jabariyah, ia pun menolak paham Qadariyah, yang dianggapnya sebagai menyerupai kaum Majusi, karena paham ini mengakui juga mashî́ah dan qudrah selain yang datang dari Allah. Menurutnya:

$$
\text { والمقصود هنا ان القد رية النافية يشبهون المجوس في كوفم اثبتوا غير الله، يحد ث اشياء من }
$$


"Maksudnya: Paham Qadariyyah Nâfiyyah (yang menafikan bahwa semua kehendak adalah kehendak-Nya) menyerupai kaum Majusi dalam hal menetapkan adanya kehendak selain kehendak Allah, bahwa keburukan (misalnya) muncul tanpa kehendak, kekuasaan, dan ciptaan-Nya" (al-Hanbalî $1425 \mathrm{H}$ ).

Lalu bagaimana Ibn Taymiyah mengompromikan kedua pendapatnya yang tampak bertentangan tersebut? Atau dengan ungkapan pertanyaan lain, di mana posisi Ibn Taymiyah dari kedua kelompok Jabariyah dan Qadariyah yang ia tolak?

Mengikuti keterangan Ibn Taymiyah mengenai pendiriannya dalam masalah kehendak Allah dan kebebasan manusia sebagaimana keterangan terdahulu, tampaknya ia pun belum bisa keluar dari jeratan kedua kelompok (paham) sebelumnya (Jabariyah dan Qadariyah) mengenai masalah yang sama. Bahkan, pendapatnya tersebut terkesan sangat ambivalent. Bagaimana mungkin hamba ('abd) dianggap sebagai pelaku (fấil) yang sebenarnya (haqîqat), jika pada saat yang sama mengakui juga bahwa Allah adalah pencipta (Khâliq) segala sesuatu, termasuk perbuatan hamba (af'âl al'ibâd)?

3. Alquran adalah Kalam Allah

Menurut Ibn Taymiyah, pendapat ulama salaf, sebagaimana yang diriwayatkan oleh 'Umar ibn Dînâr, dalam hal ini adalah:

$$
\text { الله الخالق، وما سواه مخلوق الا القرأن فانه كلا م الله غير مخلوق، منه بدأ واليه يعود. }
$$

"Allah itu pencipta. Dan selain Dia adalah makhluk. Kecuali Alquran karena sesungguhnya ia (Alquran) adalah kalam Allah, bukan makhluk. Dari-Nya bermula dan kepada-Nya kembali" (al-Hanbalî 1425 H).

Kemudian, Ibn Taymiyah memaknai kata "minhu bada'a" dalam perkataan tersebut sebagai Zat yang berbicara (al-Mutakallim bih), yang telah menurunkannya dari sisi-Nya. Sementara kata "ilayhi ya' $\hat{u} d u$ " dimaknainya sebagai diangkatnya Alquran pada akhir zaman dari dada manusia dan dari mushaf-mushaf, hingga tidak tersisa satu kalimat pun (dari Alquran) dalam dada manusia dan satu huruf pun dalam mushaf-mushaf (al-Hanbalî 1425 $\mathrm{H})$. 
Menurut Ibn Taymiyah, Alquran yang diturunkan kepada Nabi Muhammad itu adalah kalam Allah yang sebenarnya (huwa kalâm Allâh haqîqatan), bukan kalam selain Allah. Karenanya, tidak boleh berpendapat bahwa Alquran itu adalah hikayat (ungkapan dari) kalam Allah, atau ibarat (terjemah) dari kalam Allah. Bahkan jika Alquran itu dibaca oleh manusia, atau mereka menulisnya dalam mushaf, maka hal demikian tidak membuat Alquran itu bukan lagi sebagai kalam Allah, karena sesungguhnya perkataan (kalam) itu disandarkan (secara hakikat) kepada siapa yang mengatakannya pertama kali, bukan kepada yang mengatakannya sebagai penyampai atau perantaranya (al-Hanbalî $1425 \mathrm{H}$ ).

Selanjutnya, menurut Ibn Taymiyah, Allah berbicara (dalam Alquran, Taurat, Injil, dan sebagainya) dengan mashî́ah dan qudrah-Nya. Karenanya, maka perkataan-Nya (kalam-Nya) adalah "ada bersamaan dengan Zat-Nya (Qâ’im bi Dhâtih)", bukan makhluk yang terpisah dari-Nya. Tidak seorang pun dari kalangan salaf berkata bahwa kalam Allah adalah makhluk yang terpisah dari-Nya. Tidak pula mereka berkata bahwa Alquran, Taurat, dan Injil adalah "ada secara azali dan selamanya (azalan wa abadan), juga tidak berkata bahwa kalimat-kalimat itu sendiri yang ada dalam Alquran, Taurat, dan Injil adalah "ada secara qadîm dan azali (qadimat azaliyah)", tetapi yang dimaksud dengan kalam-Nya yang qadîm tersebut adalah bahwa sesungguhnya Allah tidak pernah berhenti berbicara ketika berkehendak (berbicara) (al-Hanbalî $1425 \mathrm{H}$ ).

Ada juga sebagian pendapat yang mengatakan bahwa yang makhluk adalah huruf-huruf yang terdapat dalam Alquran, bukan kalam Allah itu sendiri. Karenanya, pendapat ini membedakan antara "kitab Allah" dan "kalam Allah." Kitab Allah adalah huruf-hurufnya, dan itulah yang makhluk, sementara kalam Allah adalah maknanya yang tidak termasuk makhluk.

Menanggapi pendapat tersebut di atas, Ibn Taymiyah berkata bahwa pendapat tersebut tidak dipunyai oleh jumhûr umat, ahl al-hadith, figh, tașawwuf dan kelompok yang mendasarkan diri pada kitab dan athar (salaf), karena mereka (jumhĥr) meyakini bahwa Alquran itu adalah kalam Allah. Mereka juga tidak menjadikannya sebagian sebagai kalam Allah dan sebagian yang lain bukan kalam Allah sebagaimana pendapat di atas. Menurut mereka (jumhûr), Alquran adalah Alquran, sebagaimana yang diketahui kaum muslim, baik itu huruf-hurufnya maupun maknanya. 
Sebagaimana dapat dipahami bahwa perintah dan larangan itu dapat dipahami karena adanya lafal dan makna sekaligus (al-Hanbalî $1425 \mathrm{H}$ ):

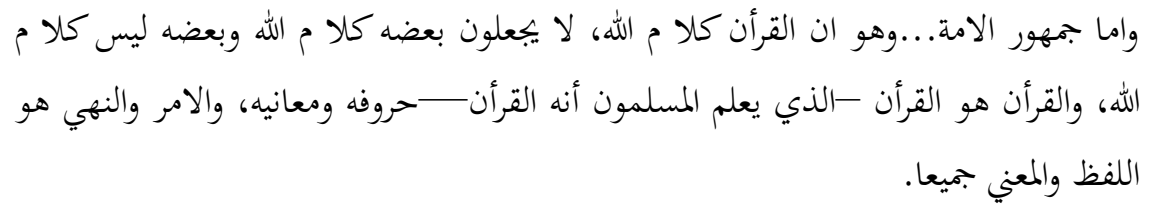

"Dan adapun jumhûr umat (menyatakan)... Dan bahwa Alquran itu kalam Allah. Mereka tidak menjadikan sebagiannya sebagai kalam Allah dan sebagian yang lain bukan kalam Allah. Alquran adalah Alquran - seperti yang diketahui kaum muslimin - baik huruf-huruf maupun mana-maknanya, sebagaimana perintah dan larangan itu adalah lafadz dan makna sekaligus."

Dengan demikian, jika dipahami bahwa yang dimaksud Alquran itu adalah huruf-huruf beserta maknanya sekaligus, maka "kalam Allah" yang terdapat dalam kitab suci-Nya, yakni Alquran, Taurat, dan Injil juga mencakup huruf-huruf beserta maknanya, bukan hurufnya saja tanpa makna dan bukan juga maknanya saja tanpa huruf.

\section{Makna Iman}

Mengenai kata "iman," menurut Ibn Taymiyah, sebagaimana yang terdapat pada penamaan sesuatu yang lain, misalnya nama-nama Allah yang banyak (al-Asmâ' al-Husnâ), nama-nama tersebut semuanya menunjukkan pada Zat yang satu. Ataupun nama-nama kitab-Nya, misalnya al-Qur'ân, alFurqân, al-Kitâb, al-Hudâ, al-Bayân, al-Shifâ', al-Nûr, dan lain sebagainya, semuanya menunjuk pada kitab suci yang satu. Atau juga nama-nama rasulNya, seperti Muhammad, Aḥmad, al-Mahî, al-Hâsiir, al-Muqfî, Naby alRahmat, Naby al-Tawbat, Naby al-Malhamah, dan sebagainya, adalah namanama untuk satu pribadi agung Nabi Muhammad. Maka demikian juga dengan nama-nama agama-Nya, yang mempunyai nama "iman," kebaikan (birr), taqwa, kebaikan (khayr), agama (dîn), perbuatan baik (amal ṣâlih), jalan yang lurus (șirât mustaqîm"), dan sebagainya, semuanya menunjukkan pada hakikat yang satu: "agama Allah."

Menurut Ibn Taymiyah, ulama salaf mendefinisikan iman sebagai perkataan dan perbuatan, yakni perkataan hati dan lisan, serta perbuatan hati dan anggota badan. Bagi yang menghendaki adanya keyakinan (i tiqâd) dalam cakupan iman, karena mereka memahami "perkataan" tersebut tidak mencakup keyakinan, tetapi hanya mencakup perkataan zahir. Sedangkan 
bagi yang menambahnya dengan niat, karena kata "perbuatan" tidak mencakup niat, begitu juga kata "perkataan," yang hanya mencakup perkataan hati dan lisan. Yang termasuk perbuatan hati misalnya mencintai Allah dan Rasul-Nya, takut kepada Allah, mencintai apa yang dicintai Allah dan Rasul-Nya, membenci apa yang dibenci Allah dan Rasul-Nya, beramal ikhlas karena Allah, tawakal, dan sebagainya (al-Ḥanbalî 1425 H).

Ibn Taymiyah sangat menekankan aspek "perkataan" dan "perbuatan" sekaligus dalam konsepsinya mengenai iman. Karenanya, konsepsinya tentang iman sangatlah luas, karena ia menyamakan kata "îmân" dengan kata "al-birr," "al-taqwâ," dan "al-dîn" (sebagaimana keterangan terdahlu). Maka menurutnya, semua yang dicintai Allah termasuk kategori "iman." Demikian juga dengan "al-birr," "al-taqwâ," dan "al-dîn," semua yang dicintai-Nya termasuk kategori ketiganya. Dalam hal ini, Ibn Taymiyah mengeluarkan sebuah hadis (untuk menunjukkan bahwa cakupan iman tersebut sangat luas) (al-Hanbalî $1425 \mathrm{H}$ ):

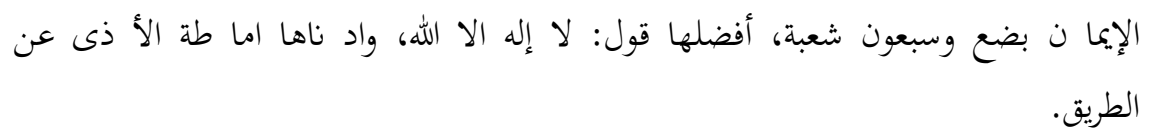

"Iman itu memiliki tujuh puluh cabang, yang paling utama adalah perkataan 'Tidak ada tuhan selain Allah.' Yang paling rendah adalah menyingkirkan duri dari jalan raya."

Menurut Ibn Taymiyah, berdasarkan beberapa hadis dan riwayat beberapa sahabat, seringkali kata iman diidentikkan dengan "al-birr," sebagaimana riwayat Abû Dhar al-Ghiffârî yang bertanya kepada Nabi Muhammad mengenai persoalan iman, Nabi pun kemudian membacakan Q.S. al-Baqarah [2]: 177:

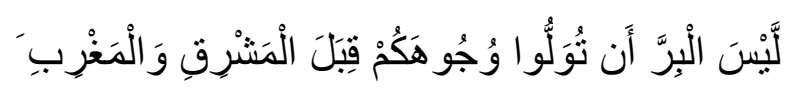

"Kebaikan itu bukanlah kalian menghadapkan wajah kea rah timur dan barat..." (al-Hanbalî $1425 \mathrm{H}$ ).

Tetapi kemudian, kata "al-birr" tersebut disifati (dan dilengkapi) dengan amal perbuatan, misalnya dengan (sebagaimana dalam firman-Nya dalam Q.S. al-Baqarah [2]: 177): 


$$
\text { وأ تى المال على حبه ذذو القر بلى واليتا مى ... }
$$

“... Dan mengeluarkan harta yang dicintainya kepada sanak kerabat dan anakanak yatim...” (al-Hanbalî $1425 \mathrm{H}$ ).

Dengan demikian - bahwa kedua aspek perkataan dan perbuatan harus ada dalam konsep iman - maka iman menjadi cacat dan tidak sempurna jika aspek perbuatannya diabaikan (demikian juga sebaliknya). Menurutnya, iman itu dapat menjadi cacat, hanya karena dalam konsep iman tersebut terkandung aspek perbuatan, bahkan menurutnya, jika seseorang berkata bahwa dengan meninggalkan perbuatan (yang diperintah), iman itu masih sempurna, maka perkataan ini adalah bentuk kekafiran yang nyata. Kata Ibn Taymiyah (al-Hanbalî 1425 H):

$$
\text { فا ن كثيرا من الفساق والمنافقين يقولون: لا يضر مع الا يما ن ذ نب اومع التو حيد. }
$$

"Maka sesungguhnya di antara orang-orang fasik dan munafik ada yang berkata: "iman tidak rusak dengan dosa atau pun tauhid."

Ibn Taymiyah tidak sependapat dengan kalangan yang mempunyai pendapat bahwa jika seseorang dihukumi kafir oleh Syari', maka ia akan kekal dalam neraka, karena dalam hatinya tidak terdapat "pengetahuan" dan "pembenaran." Menurutnya, pendapat ini sangat bertentangan dengan akal sehat dan syara', karena manusia secara fitrah pasti mampu membedakan antara yang haq dan yang batil, tetapi kebanyakan menusia menyimpang dari jalan kebenaran karena lebih disebabkan penyakit hasad, cinta dunia, harta, kekuasaan, dan lain sebagainya (al-Hanbalî 1425 H). Maka ia pun menukil sebuah hadis berikut:

$$
\text { يخر ج من النا ر من في قلبه مثقال ذ رة من ايمان. }
$$

"Orang yang di dalam hatinya terdapat iman sebesar biji akan dikeluarkan dari neraka."

Hal ini sesuai dengan ayat: 


$$
\text { فمن يعمل مثقال ذ رة خيرا يراه، ومن يعمل مثقال ذرة شرا يرا هـ }
$$

"Maka saipa pun yang berbuat kebaikan (meskipun) sebesar biji, maka Allah (pasti) melihatnya. Dan siapa pun yang berbuat keburukan (meskipun) sebesar biji, Allah (pasti) melihatnya" (Q.S. al-Zalzalah [9]: 7)

Dalam konteks ini, Ibn Taymiyah menafsiri lafadz mithqâl dharrah min khayr "sebesar biji dari kebaikan" sebagai mithqâl dharrah min îmân atau "sebesar biji dari keimanan" (al-Hanbalî $1425 \mathrm{H}$ ).

\section{Menimbang Pemikiran Kalam Ibn Taymiyah}

Ibn Taymiyah, sebagaimana telah dijelaskan pada bagian pendahuluan di atas, membagi kelompok yang memahami akidah Islam ke dalam empat kategori (filsuf, pakar ilmu kalam, ulama yang mengadakan penalaran terhadap akidah yang terdapat di dalam Alquran untuk diimani, dan kelompok orang yang beriman kepada Alquran tetapi mempergunakan dalil rasional di samping dalil Alquran itu), dan dengan tegas menyatakan bahwa kelompok salaf tidak termasuk ke dalam salah satu dari keempat kelompok ini. Dalam pemahaman terhadap aqidah Islam, kelompok salaf mempunyai metode (manhaj) tersendiri yang membedakannya dengan empat kelompok di atas.

Kegigihan Ibn Taymiyah membela dan mempromosikan manhaj salaf ini to some extent dapat dipandang bahwa ia sendiri adalah pengikut setia manhaj ini. Beberapa contoh pemikiran kalam Ibn Taymiyah seperti diuraikan di atas (mengenai sifat-sifat Allah, kehendak Allah dan kebebasan manusia, Alquran adalah kalam Allah, dan makna iman) menunjukkan dengan gamblang bagaimana ia dengan setia mengikuti jalan pikir manhaj salaf ini.

Mengikuti manhaj ini, yang mencukupkan diri pada Kitab (Alquran) dan sunah Nabi dalam menjelaskan dan memahami persoalan-persoalan akidah serta tidak memasuki dunia kalam dan falsafah, Ibn Taymiyah dalam memahami sifat-sifat Allah, misalnya, sama sekali tidak melakukan tahrîf (mengubah lafal atau makna nama dan sifat), ta'tîl (menghilangkan atau meniadakan sifat-sifat Allah), takyîf (menerangkan bentuk atau keadaan sifat itu) dan tamthîl (menyerupakan dengan makhluk) (al-Hanbalî $1425 \mathrm{H}$; al-Sa'dî 2001), dan hanya menyerahkan makna dan hakikatnya kepada 
Allah semata, karena Allahlah yang menamai dan menyifati diri-Nya sendiri dalam Kitab (Alquran) atau melalui lisan Rasul-Nya (al-Hanbalî 1425 H)

Ketika memberikan prinsip-prinsip dalam memahami nama dan sifat Allah, manhaj salaf yang Qur'âni dan hadîthi ini juga tampak bersandar pada bunyi ayat Alquran tanpa sedikit pun memberi ruang penjelasan dari selain Alquran. Di antara prinsip itu adalah pertama, kaum mukmin akan melihat Allah di surga dan mereka merasakan nikmat dengan melihat-Nya, dekat dengan-Nya, dan mendapat rida-Nya (seperti tertera dalam Q.S. alQiyâmah [75]: 22; Q.S. al-Qiyâmah [75]: 23; Q.S. al-Muțaffifîn: 35; Q.S. alQâf [45]: 35). Kedua, prinsip yang sudah tetap adalah prinsip ma'iyah (kebersamaan) Allah. Ma iyah adalah salah satu sifat dari sifat-sifat Allah (seperti disebutkan dalam Q.S. al-Baqarah [2]: 194; Q.S. al-Baqarah [2]: 153; Q.S. Tâhâ [20]: 46; Q.S. al-Tawbah [9]: 40). Ketiga, prinsip yang menetapkan ketinggian Allah di atas makhluk-Nya, dan istiwâ' di atas 'Arash (al-Sa'dî 2001).

Dengan prinsip-prinsip ini dan dengan manhaj salaf ini secara keseluruhan, muncul kesan yang kuat bahwa manhaj ini, yang dipegang teguh oleh Ibn Taymiyah dan sekaligus ia menjadi tokoh utamanya, kurang mengapresiasi penggunaan akal dalam memahami ajaran-ajaran keagamaan yang bersumber dari Alquran dan hadis termasuk dalam memahami persoalan-persoalan akidah Islam. Pertanyaannya, di mana posisi akal, menurut Ibn Taymiyah, ketika berhadapan dengan ayat-ayat Alquran maupun hadis-hadis Nabi?

Dalam kaitannya dengan soal-soal keagamaan, Ibn Taymiyah memang memosisikan akal di belakang ayat-ayat suci Alquran yang menjadi sumber ajaran Islam. Fungsi akal terhadap ajaran keagamaan ini, menurut Ibn Taymiyah, hanya merupakan alat untuk memahami nas-nas Alquran dan sunah, tidak lebih. Namun di saat yang sama, Ibn Taymiyah juga mengapresiasi akal sebagai alat berpikir dengan merujuk pada ayat Alquran seperti (Amin 1991):

"Ini adalah sebuah kitab yang Kami turunkan kepadamu penuh dengan berkah supaya mereka memperhatikan ayat-ayat-Nya dan supaya mendapat pelajaran orang-orang yang mempunyai pikiran" (Q.S. Șâd [38]: 29).

Atau ayat berikut:

"Maka apakah mereka tidak memperhatikan al-Quran?" (Q.S. al-Nisâ' [4]: 82). 
Menurut Ibn Taymiyah, antara dalil-dalil naqlî (yang bersumber dari Alquran dan hadis) dan dalil-dalil 'aqli (yang bersumber dari pemikiran akal) tidak mungkin bertentangan, selama dalil-dalil naqlî yang dijadikan pedoman tersebut benar-benar șahîh dan dalil-dalil 'aqlî yang dipergunakan tersebut benar-benar șarîh. Namun, jika memang terdapat pertentangan di antara keduanya, dan jika terdapat ketidaksamaan antara pendapat akal dengan petunjuk (lahiriyah) wahyu mengenai suatu masalah, maka pendapat akal harus tunduk pada ketentuan wahyu. Dalam kaitan antara pendapat akal dan ketentuan syara' ini, Ibn Taymiyah berpegang pada dua prinsip di bawah ini (Amin 1991):

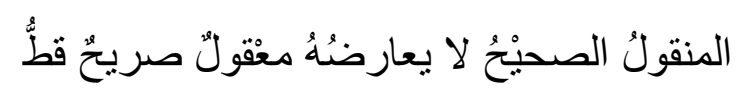

"Dalil-dalil 'aqlî yang șarîh tidak akan bertentangan sama sekali dengan dalil-dalil naqlî yang șahîh."

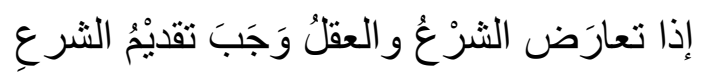

"Jika (ketentuan) syara' bertentangan dengan (pendapat) akal, maka (ketentuan) syara' harus didahulukan.”

Persoalan penyandaran pengetahuan apakah pada otoritas wahyu ataukah pada pendapat akal, seperti dalam kasus Ibn Taymiyah di atas, sebenarnya termasuk persoalan apa yang dalam filsafat ilmu disebut epistemologi. Epistemologi membahas apa yang disebut sebagai filsafat pengetahuan. Terdapat tiga persoalan pokok dalam epistemologi. Pertama, apa sumber pengetahuan itu? Dari mana pengetahuan yang benar itu datang? Bagaimana kita mengetahui? Kedua, apa watak pengetahuan itu? Apakah ada dunia riil di luar pikiran kita, kalau ada, apakah kita dapat mengetahuinya? Ketiga, apakah pengetahuan kita itu benar? Bagaimana kita dapat membedakan pengetahuan yang benar dari pengetahuan yang salah? (Titus, Smith, dan Nolan 1984).

Kajian epistemologi menarik dibincangkan karena berkaitan erat dengan perolehan pengetahuan yang benar (valid). Dalam kaitannya dengan pemikiran seorang tokoh, kajian epistemologi penting didiskusikan terutama untuk mengetahui corak pemikiran sang tokoh. Dalam kepentingan ini, tulisan ini hendak mengenalkan pemikiran Muhammad 
'Âbid al-Jâbirî mengenai epistemologi yang berkembang di dunia Islam terlebih dahulu sebelum masuk pada pembahasan epistemologi yang diusung oleh Ibn Taymiyah.

Al-Jâbirî mengelompokkan epistemologi yang berkembang di dunia Islam (tepatnya mengelompokkan nalar Arab) ke dalam tiga kelompok, yaitu nalar burhânî (episteme rasional yang berasal dari Yunani), bayân̂̂ (episteme bahasa yang berasal dari kebudayaan Arab), dan nalar 'irfân̂̂ (episteme gnosis yang berasal dari tradisi Persia dan Hermetis). Nalar yang pertama adalah bentuk nalar yang menurutnya perlu dikembangkan oleh kaum Muslim kini, sedangkan kedua nalar yang terakhir menjadi sasaran kritiknya (Washil 2003).

Dari ketiga nalar pemikiran ini, pendirian Ibn Taymiyah yang lebih mengutamakan pengetahuan wahyu ketimbang pengetahuan akal, yang membatasi diri pada wilayah permukaan bahasa, dan menghindari pola pikir takyîf (menerangkan bentuk atau keadaan sifat) bisa dipandang lebih dekat pada nalar bayânî ketimbang dua nalar yang lain. Unsur-unsur yang dominan dari nalar bayânî, menurut al-Jâbirî, adalah membatasi diri pada wilayah permukaan bahasa dengan menghindari ta'wîl, menganut pandangan "lâ kayfa" (tidak banyak bertanya soal mengapa dan bagaimana), berpegang teguh pada format-format bahasa dan bentuk-bentuk bayânî (keindahan dan kekuatan bahasa bagai sihir yang memukau) yang bersifat inderawi, membatasi diri pada satu definisi yang menggambarkan sifat (ta'rîf bi al-rasm) dan bukan substansi dan hakikat (ta'rif bi al-had) (Washil 2003).

Lalu, menurut al-Jâbirî, dalam konteks pemikiran Islam modern (lebih tepatnya Arab modern-kontemporer), kecenderungan pemikiran yang tekstualis-literalis, salafiyah, dan tradisionalisme (așâlah) sebenarnya dapat dirujukkan pada kerangka sistem nalar bayânî ini meskipun sebagian saja, sebagaimana kecenderungan lain yang mendukung modernitas (mu'ạsarah) mendapatkan pijakannya pada sistem nalar burhânî.

Kita tidak akan memperpanjang tarik menarik di antara dua nalar (bayânî dan burhânî) ini, yang al-Jâbirî sendiri berpihak pada nalar burhânî. Tulisan ini hanya hendak mengatakan bahwa dalam pemetaan epistemologi yang dilakukan al-Jâbirî, pendirian epistemologis Ibn Taymiyah lebih dekat dengan nalar burhân̂̀ ketimbang burhânî dan 'irfân̂. Andai mengikuti kecenderungan dan keberpihakan al-Jâbirî, tentu pendirian epistemologis Ibn Taymiyah ini menjadi bagian dari sasaran kritik al-Jâbirî karena ia hanya mendukung dan mempromosikan nalar burhânî. 
Dengan pendirian epistemologis ini, yang menolak semua otoritas kecuali nas-nas keagamaan (wahyu), Ibn Taymiyah - dalam istilah Nurcholish Madjid - menjadi seorang egalitarianis radikal. Ia menjadi amat kritis kepada hampir semua pemikiran Islam yang mapan, terutama falsafah dan kalam, juga terhadap disiplin ilmu yang dianggapnya berasal dari dunia luar Islam seperti ilmu-ilmu Yunani (Madjid 2007). Karenanya, tidak heran jika Ibn Taymiyah terkenal dengan kritiknya yang tajam terhadap logika Aristoteles.

Dalam upayanya mengritik logika Aristoteles, Ibn Taymiyah telah menyusun dua kitab logika, yakni Kitab al-Radd ala al-Mantiqiyyîn (Penolakan terhadap para Ahli Logika) dan Naqd al-Mantiq (Kritik Logika). Dalam kedua kitab ini, Ibn Taymiyah melancarkan kritik terutama pada term-term penting logika Aristoteles, yakni term konsep/definisi, proposisi, dan silogisme. Terhadap definisi, Ibn Taymiyah mengemukakan sepuluh kritik yang ia tulis dalam dua kitabnya tersebut. Di antara kritiknya terhadap definisi, seperti dikutip Zainun Kamal (Kamal 2006), adalah:

Pertama, bagi Aristoteles, definisi adalah pernyataan yang menunjuk pada hakikat atau substansi sesuatu yang didefinisikan. Menurut Ibn Taymiyah, jika definisi adalah pernyataan dari si pembuat definisi, maka si pembuat definisi pasti tahu bahwa sesuatu yang didefinisikan itu juga diketahuinya dengan definisi, atau ia mengetahui tanpa definisi. Jika yang pertama, maka rentetan definisi dibutuhkan, dan ini tidak masuk akal. Jika yang kedua, maka proposisi "hakikat sesuatu diketahui dengan definisi" batal dengan sendirinya.

Kedua, para fuqahâ', ahli tata bahasa, dokter, ahli hitung, dan sebagainya adalah orang-orang yang ahli di bidangnya masing-masing, dan mereka telah menerapkan ilmu mereka dalam bidang usaha praktis. Padahal tidak seorang pun di antara mereka yang mengetahui dan membutuhkan definisi logis. Namun, mereka dapat memahami konsep dan kata dalam bidang ilmu mereka.

Ketiga, tidak pernah terdapat suatu kesepakatan kata, atau satu kesepakatan definisi dalam satu cabang ilmu. Bahkan dalam definisi "manusia" yang sudah popular, yaitu "hewan yang berpikir" masih terdapat perdebatan hebat. Ahli tata bahasa Arab mendefinisikan ism lebih dari dua puluh definisi. Ahli ushul menyebutkan definisi qiyâs lebih dari dua puluh definisi dan masing-masingnya saling bertentangan. Sampai saat ini, tidak seorang pun berhasil membuat satu definisi yang disepakati. 
Demikian di antara kritik Ibn Taymiyah terhadap logika Aristoteles. Terdapat satu perbedaan epistemologis di antara keduanya. Aristoteles bertolak dari pendirian epistemologis bahwa kebenaran dapat diperoleh melalui logika. Sedangkan Ibn Taymiyah bertolak dari keyakinan bahwa kebenaran hanya diperoleh melalui ajaran wahyu. Ilmu logika, menurut Ibn Taymiyah, tidak diperlukan dalam Islam karena Nabi Muhammad sendiri tidak mengenal logika Aristoteles. Demikian pula para Sahabat dan salaf saleh, mereka tidak mengenal logika Aristoteles namun mereka lebih memahami ajaran agama daripada kita (Kamal 2006). Sekalipun mengritik logika Aristoteles, namun Madjid melihat, Ibn Taymiyah bukannya sama sekali meninggalkan logika Aristotelian ini. Ia mengritik keras logika Aristotelian ini namun ia tidak dapat menghindarinya. Dalam kasus berikut ini, ia tampak ambigu. Dalam mengritik metode ijmâ' dalam mazhab Shâfi'î, misalnya, Ibn Taymiyah menekankan pentingnya qiyâs shar'î yang benar. Di sini ia bertemu lagi dengan ilmu logika. Bukunya, al-Qiyâs fi alshar' al-Islâmî, dimulai dengan penegasan bahwa qiyâs shar'î yang benar ialah yang didasarkan kepada silogisme yang berusaha menemukan bukannya kesamaan-kesamaan dangkal di antara syarat-syaratnya, namun faktor penyebab ('illah) yang ada. Pembelaannya terhadap qiyâs ini pada akhirnya bersifat Aristotelian juga (Madjid 2007).

Tidak hanya dengan Aristoteles, Ibn Taymiyah juga tidak sependapat dengan para filsuf Muslim, terutama al-Fârâbî, Ibn Sînâ, Ibn Rushd, dan al-Ghazâlî, yang menerima logika Aristoteles. Tidak sama dengan tiga filsuf yang lain, al-Ghazâlî, meskipun percaya pada kebenaran logika, ia memosisikan logika akal di belakang wahyu dalam persoalan metafisika karena ia di luar batas kemampuan akal. Adapun perbedaan alGhazâlî dengan Ibn Taymiyah adalah al-Ghazâlî mengritik para filsuf setelah sebelumnya bersungguh-sungguh mencari hakikat kebenaran melalui filsafat. Sedangkan Ibn Taymiyah mengritik logika Aristoteles dan filsafat setelah secara apriori meyakini wahyu sebagai satu-satunya sumber hakikat kebenaran, dan tujuannya untuk menyerangnya dalam rangka menjaga keyakinannya dari pengaruh logika dan filsafat (Kamal 2006).

Sampai di sini, ada satu hal menarik berkaitan dengan manhaj salaf yang didukung dan dipromosikan Ibn Taymiyah. Meskipun ia gigih mempertahankan manhaj ini, ia juga memperkenalkan manhaj Ahl al-Sunnah wa al-Jamâ'ah sebagai manhaj yang harus diikuti kaum Muslimin. Ciri-ciri manhaj ini adalah menempuh jalan yang lurus dan pegangan yang 
bermanfaat dari Kitab dan sunah, mengikuti orang yang paling tahu tentang Islam dan paling dalam ilmunya serta paling ittibâ' kepada Alquran dan sunah, yaitu para Sahabat, mengikuti Khulafầ al-Râshidûn secara khusus, dan berjalan di jalan Allah dengan diiringi prinsip-prinsip yang mulia ini (al-Sa'dî 2001).

Dilihat dari kandungan isinya, kedua manhaj (salaf dan Ahl al-Sunnah wa al-Jamaah) ini memang kurang lebih sama. Namun, penggunaan nama yang berbeda bisa mengundang persoalan. Tentu dibutuhkan penelitian lebih lanjut untuk mengetahui apakah keduanya memang mempunyai kandungan makna yang sama ataukah keduanya mempunyai kandungan makna dan ciri yang berbeda.

\section{Simpulan}

Ibn Taymiyah merupakan tokoh penting bagi mazhab pemikiran salafiyah (salafisme) yang berorientasi pada ajaran kembali kepada Alquran dan hadis sebagaimana yang dipraktikkan oleh kaum salaf al-sâlih. Sebagai pembaharu dan mujtahid, ia memiliki posisi penting dalam pemikiran dan peradaban Islam setelahnya, hingga kini. Pengaruh Ibn Taymiyah di dunia Islam modern saat ini secara resmi diwakili oleh gerakan Salafî-Wahhâbî. Meskipun dicitrakan negatif, namun beberapa penelitian menunjukkan hal sebaliknya.

Salafî memiliki beberapa perbedaan dari aliran-aliran pemikiran kalam yang selama ini ada. Ia tidak sependapat dengan pendapat Qadariyyah dan Jabariyah terkait dengan kehendak mutlak Allah dan kebebasan manusia. Ia mencoba membuat rumusan sendiri yang berbeda, penjelasannya sendiri belum begitu meyakinkan. Pendapat-pendapatnya yang terpaku pada mana tekstual suatu nas, juga membuatnya berbeda dari teologi yang dianut oleh kalangan Ahl al-Sunnah wa al-Jamâ'ah lainnya.

Allâhu a'lam

\section{Daftar Pustaka}

Abû Zahrah, Muhammad. 1996. Aliran Politik Dan Aqidah Dalam Islam. Terj. Ahmad Dahlan, Abdu Rahman, dan Qarib. Jakarta: Logos Publishing House.

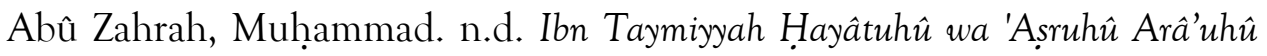
wa Fiqhuhû. Beirut: Dâr al-Fikr. 
Afwadzi, Benny dan Nur Alifah. 2017. "Waktu Puasa Arafah Perspektif Muhammad Bin Shalih Al "Utsaymin: Telaah Kajian Hukum Islam dan Astronomi Islam.” Ulul Albab: Jurnal Studi Islam 18(2): 161-83.

Amin, Muhammad. 1991. Ijtihad Ibn Taimiyah Dalam Bidang Fikih Islam. Jakarta: INIS.

Ardiansyah. 2013. "Pengaruh Hanbali dan Ibn Taymiyah Terhadap Gerakan Salafi.” Analytica Islamica 2(2): 246-61.

Chirzin, Muhammad. 1999. Pemikiran Tauhid Ibnu Taimiyah Dalam Tafsir Surat Al-Ikhlas. Yogyakarta: Dana Bhakti Prima Yasa.

Damayanti, Melvia, dan Adi Cilik Pierewan. 2016. "Prasangka Sosial Terhadap Salafi Di Yogyakarta.” Pendidikan Sosiologi UNY: 1-20.

al-Gharabî, 'Alî Muștafâ. 1958. Târikh al-Firâq al-Islâmiyah wa Nash'at 'Ilm alKalâm 'ind al-Muslimîn. Mesir: t.p.

al-Hanbalî, 'Abd al-Raḥmân ibn Muḥammad ibn Qâsim al-Ậșimî al-Najdî. 1425 H. Majmû' Fatâwâ Shaykh al-Islâm Ahmad ibn Taymiyah, Vol. 3. Beirut: Dâr al'Arabiyah.

al-Ḥanbalî, 'Abd al-Raḥmân ibn Muhammad ibn Qâsim al-'Ạ̣̣imî al-Najdî. 1425 H. Majmû' Fatâwâ Shaykh al-Islâm Ahmad ibn Taymiyah, Vol. 4. Beirut: Dâr al'Arabiyah.

al-Hanbalî, 'Abd al-Raḥmân ibn Muhammad ibn Qâsim al-Âșimî al-Najdî. 1425 H. Majmû' Fatâwâ Shaykh al-Islâm Ahmad ibn Taymiyah, Vol. 7. Beirut: Dâr al-'Arabiyah.

al-Ḥanbalî, 'Abd al-Raḥmân ibn Muhammad ibn Qâsim al-Âṣimî al-Najdî. 1425 H. Majmî‘ Fatâwâ Shaykh al-Islâm Ahmad ibn Taymiyah, Vol. 8. Beirut: Dâr al-'Arabiyah.

al-Hanbalî, 'Abd al-Raḥmân ibn Muhammad ibn Qâsim al-Ậșimî al-Najdî. 1425 H. Majmû' Fatâwâ Shaykh al-Islâm Ahmad ibn Taymiyah, Vol. 12. Beirut: Dâr al-'Arabiyah.

Harold H. Titus, Marilyn S. Smith, dan Richard T. Nolan. 1984. PersoalanPersoalan Filsafat. Terj. Rasjidi. Jakarta: Bulan Bintang.

Hudaya, Hairul. 2008. "Kritik Ibn Taymiyah Terhadap Paham Wahdatul Wujud.” Al-Banjari: Jurnal Ilmiah Ilmu-Ilmu Keislaman 7(2): 165-86. 
Kamal, Zainun. 2006. Ibn Taymiyah Versus Para Filosof: Polemik Logika. Jakarta: Raja Grafindo Persada.

Madjid, Nurcholish. 2007. Khazanah Intelektual Islam. Jakarta: Bulan Bintang.

Madjid, Nurcholish. 1992. Islam, Doktrin dan Peradaban. Jakarta: Paramadina.

al-Maḥmûd, 'Abd al-Raḥmân ibn Ṣâliḥ ibn Ṣâliḥ. 1995. Mawqîf Ibn Taymiyah min al-Ashấirah, Vol. 2. Riyâd: al-Rushd.

Mansur, Laily. 1994. Pemikiran Kalam Dalam Islam. Jakarta: Pustaka Firdaus.

Nasution, Harun. 1972. Teologi Islam Aliran-Aliran Sejarah Analisa Perbandingan. Jakarta: UI Press.

Noorhayati, S Mahmudah, dan Ahmad Khoirul Fata. 2017. "Exclusive Islam From The Perspective of Ibn Taymiyah.” Esensia: Jurnal Ilmu-Ilmu Ushuluddin 18(2): 213-23.

Rohmaniyah, Inayah, dan Mark Woodward. 2012. "Wahhabism, Identity and Secular Ritual: Graduation at Indonesian High School." AlJami'ah: Journal of Islamic Studies 50(1): 129-45.

al-Sa'dî, 'Abd al-Raḥmân ibn Nâșir. 2001. Sharh al-Aqîdat al-Wasị̣iyah. Jakarta: Dar al-Haq.

al-Shahrastânî. n.d. Al-Milal wa al-Nihal. Beirut: Dâr al-Fikr.

Sucipto. 2011. "Pembaharuan Hukum Islam (Studi Terhadap Pemikiran Hukum Ibnu Taimiyah).” Asas: Jurnal Hukum dan Ekonomi Islam 3(1): 50-64.

Washil, Izzuddin. 2003. "Dilema Tradisi Dan Modernitas Telaah Atas 'Kritik Nalar Arab' Muhammad Abid Al-Jabiri.” Khatulistiwa: Journal of Islamic Studies 2(3): 101-12.

Washil, Izzuddin, dan Ahmad Khoirul Fata. 2017. "Pemikiran Ibn Taymiyah Tentang Syariah Sebagai Tujuan Tasawuf." Teosofi: Jurnal Tasawuf dan Pemikiran Islam 7(2): 316-38. 